S. Tobita $\cdot$ O. Ito $\cdot$ R. Matsunaga $\cdot$ T.P. Rao

T. J. Rego $\cdot$ C. Johansen $\cdot$ T. Yoneyama

\title{
Field evaluation of nitrogen fixation and use of nitrogen fertilizer by sorghum/pigeonpea intercropping on an Alfisol in the Indian semi-arid tropics
}

Received: 21 May 1993

\begin{abstract}
A field experiment was conducted to obtain the $\mathrm{N}$ balance sheet for sole crops and intercrops of sorghum [Sorghum bicolor (L.) Moench] and pigeonpeas [Cajanus cajan (L.) Millsp.]. Intercropping gave a significant advantage over sole cropping in terms of dry matter produc* tion and grain yield, as calculated on the basis of the land equivalent ratio and area-time equivalent ratio. The $\mathrm{N}$ fertilizer use efficiency and atmospheric $\mathrm{N}_{2}$ fixation by pigeonpea were estimated using ${ }^{15} \mathrm{~N}$-labeling and natural abundance methods. The $\mathrm{N}$ fertilizer use efficiency of sorghum was unaltered by the cropping system, while that of the pigeonpea was greatly reduced by intercropping. Although intercropping increased the fractional contribution of fixed $\mathbf{N}$ to the pigeonpeas, no significant difference was observed between the cropping systems in total symbiotically fixed $\mathrm{N}$. There was no evidence of a signifi. cant transfer of $\mathrm{N}$ from the pigeonpea to the sorghum. This study showed that use of soil $\mathbf{N}$ and fertilizer $\mathbf{N}$ by pigeonpeas was almost the same as that by sorghum in sole cropping, indicating the potential competence of pigeonpeas to exploit soil $\mathbf{N}$. However, when $\mathrm{N}$ was exhausted by a companion crop in intercropping, the pigeonpea crop increased its dependency on atmospheric $\mathrm{N}_{2}$ fixation. We conclude that knowledge of how $\mathrm{N}$ from different sources is shared by companion crops is a prerequisite to establishing strategies to increase $\mathrm{N}$ use, and consequently land productivity, in intercropping systems.
\end{abstract}

ICRISAT Journal Article No. JA-1473

S. Tobita' ${ }^{\prime}$ O. Ito $(\otimes) \cdot$ R. Matsunaga ${ }^{2} \cdot$ T.P. Rao

T. J. Rego - C. Johansen - T. Yoneyama ${ }^{3}$

International Crops Research Institute

for the Semi-Arid Tropics (ICRISAT),

Patancheru, A.P. 502 324, India

Present addresses:

'Tropical Agriculture Research Center, Okinawa branch,

Ishigaki, Okinawa, 907 Japan

${ }^{2}$ Tropical Agriculture Research Center, Ohwashi, Tsukuba,

Ibaraki, 305 Japan

${ }^{3}$ National Agriculture Research Center, Tsukuba,

Ibaraki, 305 Japan
Key words Fertilizer use efficiency - Intercropping Natural ${ }^{15} \mathrm{~N}$ abundance . Niırogen fixation - Pigeonpea - Sorghum

\section{Introduction}

Cereal/legume intercropping has been practised traditionally throughout the developing countries of the tropics, especially in the semi-arid regions. Intercropping has the potential to achieve a higher grain yield and greater land use efficiency per unit area than sole cropping, through efficient use of resources, such as light, water, and nutrients (Willey 1979). Improvement of soil fertility due to $\mathrm{N}$ amendment by legumes has been considered a major advantage of cereal/legume intercropping. Although many papers have reported a yield advantage with cereal/legume intercropping systems (Eaglesham et al. 1981; Bandyopadhyay and De 1986; Elmore and Jackobs 1986; Patra et al. 1986; Danso et al. 1987; Papastylianou 1988; van Kessel and Roskoski 1988; Papastylianou and Danso 1991), few have dealt with the $\mathrm{N}$ economy within the system. $\mathrm{N}$ budgets in intercropping systems seem to be strongly affected by crop combinations, soil available- $\mathrm{N}$ levels, and other environmental factors.

The intercropping combination of early-maturing sorghum and late-maturing pigeonpeas is widely practised by farmers in India. Intensive studies have mainly focused on the agronomic performance of the cropping system, revealing that the intercropped pigeonpea suffers considerable competition for light because of the vigorous growth of the sorghum (Willey et al. 1981). However, relatively less information is available on the underground competition for resources in intercropping systems.

In the present studies, we examined the intercropping effects of the $\mathrm{N}$ economy of the component crops, i.e., $\mathrm{N}_{2}$ fixation by the pigeonpea and uptakes of fertilizer and soil $\mathbf{N}$ by both crops. Four levels of fertilizer $\mathbf{N}$ application were used because the critical $\mathbf{N}$ level, at which competition between the companion crops for $\mathrm{N}$ uptake 
becomes intense, is unknown. To evaluate $\mathrm{N}$ use efficien$c y,{ }^{15} \mathrm{~N}$-enriched fertilizer was applied in one part of the experiment, and to better estimate $\mathrm{N}_{2}$ fixation, the natural is $\mathrm{N}$ abundance method was also adopted in another part.

\section{Materials and methods}

\section{Treatments and experimental design}

The experiment was conducted during the 1991 rainy season on a medium-deep Alfisol at the ICRISAT Center, Patancheru $\left(18^{\circ} \mathrm{N}\right.$, $\left.78^{\circ} \mathrm{E}\right)$, India. The soil had an available moisture storage capacity of about $100 \mathrm{~mm}$ and was inherently low in fertility $(57,10$, and $200 \mathrm{mg} \mathrm{kg}^{-1}$ of available N, P, and K, respectively). Medium-duration pigeonpeas [Cajanus cajan (L.) Millsp. cv. ICP 1-6] and grain sorghum [Sorghum bicolor (L.) Moench cv. CSH 5] were sown on 20 June, immediately after the onset of the rainy season. The interrow spacing was fixed at $60 \mathrm{~cm}$. The intra row spacing differed among the cropping $\$ y s t e m$, with $15 \mathrm{~cm}$ for sole sorghum, $30 \mathrm{~cm}$ for sole pigeonpea, and $10 \mathrm{~cm}$ for both crops in the intercropping, which had a 2:1 (sorghum : pigeonpea) row proportion. This arrangement gave an identical number of plants on an area basis for each component crop in the sole and intercropping systems. Four levels of $\mathrm{N}$ fertilizer, $0,25,50$, and $100 \mathrm{~kg} \mathrm{~N}^{-1}$ as urea, were broadcast before sowing. $P$ was applied basally to all treatments at the rate of $20 \mathrm{~kg} \mathrm{ha}$ ' as single superphosphate. The fertilizer was evenly incorporated manually into the top $15 \mathrm{~cm}$ of soil.

The experimental layout was a split-plot design with three replications. The four $\mathrm{N}$ treatments were assigned to main plots and the three cropping patterns to subplots. The subplot area was $12 \mathrm{~m}$ (towards the row direction) $\times 5 \mathrm{~m}$. Except for the no- $\mathrm{N}$ plots, " $\mathrm{N}$-labelled urea ( 3.26 atom\%, Shoko Co. Lid., Japan) was applied 10 $1 \times 1 \mathrm{~m}$ microplots, marked with iron pegs at the four corners, in the center of each subplot, at the same rate as for the surrounding ${ }^{14} \mathrm{~N}$ urea.

Growth and yield estimates

Shoot samples were collected from a $1.5 \cdot \mathrm{m}$ long row of each sole crop and a $0.9-\mathrm{m}$ row of intercropping once a month. The samples were then separated into leaves, stems + petiole, and reproductive organs, and dried at $70^{\circ} \mathrm{C}$ to determine the dry weight and $\mathrm{N}$ concentrations in the organs. The $\mathrm{N}$ concentration was determined by indophenol color formation (Chaykin 1969) after digestion with a hydrogen peroxide-sulfuric acid mixture (Singh et al. 1984). At maturity, which was 110 and 200 days after sowing for the sorghum and pigeonpea crops, respectively, entire plants were harvested to estimate the total dry weight and grain yield for each species. The land equivalent ratio (LER) and area-time equivalent ratio (ATER) were used to evaluate the biological efficiency of intercropping system relative to sole cropping. as expressed by Mead and Willey (1980) and Hiebsch and McCollum (1987), respectively.

$$
\begin{aligned}
& \text { LER }=\left(Y_{s p} / Y_{s s}\right)+\left(Y_{p s} / Y_{p p}\right) \\
& \text { ATER } \left.=\|\left(Y_{s p} / Y_{s s}\right) t_{s}+\left(Y_{m} / Y_{p p}\right) t_{p}\right] / T
\end{aligned}
$$

where $Y_{\mathrm{ss}}, Y_{\mathrm{pr}}$ are the sole crop yields of sorghum and pigeonpea, respectively. $\gamma_{\mathrm{sp}}$ and $Y_{\mathrm{ps}}$ are the respective yields from the intercrop, $Y_{m} / Y_{s s}$ and $Y_{p s} / Y_{n n}$ are the relative yield of intercropped sorghum and pigeonpea to sole crop (partial LER), and $t_{s}, t_{p}$, and $T$ are the durations of sorghum, pigeonpea, and the whole cropping system. In this trial, $t_{s}, t_{\mathrm{p}}$ and $T$ were 110,200 , and 200 days, respectively. Fallen leaves of pigeonpea were also collected and analyzed for $N$, because of their significant contribution to the dry matter and $\mathrm{N}$ budget.
Sample preparation for isotopic analysis

At harvesting time, three plants of each species were sampled from the inner rows of a ${ }^{15} \mathrm{~N}$-treated microplot. Similarly, another set of three plants was also taken for the measurement of natural ${ }^{15} \mathrm{~N}$ abundance $\left(\delta^{15} \mathrm{~N}\right)$ from the surrounding area, which was reasonably far from the microplot to avoid any contamination. In order to determine the $8^{19} \mathrm{~N}$ value of pigeonpea, short-duration plants (cv ICPL 87) were grown with an $\mathrm{N}$-free nutrient solution in a sand culture medium in a greenhouse.

For both types of ${ }^{15} \mathrm{~N}$ analyses, approximately $2 \mathrm{~g}$ finely ground plant sample was digested by the conventional Kjeldahl method with salicylic acid to convert $\mathrm{NO}_{3}^{-}$to $\mathrm{NH}_{\mathrm{d}}^{+}$. After determination of the $\mathrm{N}$ content, an adequate quantity of $\mathrm{N}(1 \mathrm{mg}$ for the enriched samples and $3 \mathrm{mg}$ for the natural abundance samples) was steam-distilled into the required volume of $0.5 \mathrm{~N}$ sulfuric acid solution to make ammonium sulfate salt. The salt was then dissolved with distilled water and made up to approximately $1.8 \mathrm{ml}$ of sample solution for subsequent analyses. $\mathrm{N}_{2}$ gas was evolved by mixing the sample solution with alkaline sodium hypobromite. The impurities in the gas were removed with the system described by Yoneyama (1987). The resultant pure $N_{2}$ gas was introduced to a mass spectrometer (Hitachi RM-I-2 for the "N-enriched samples and Fin. nigan Mat 251 for natural ${ }^{14} \mathrm{~N}$ abundance) to measure the ${ }^{15} \mathrm{~N}$ abundance in the sample.

\section{Estimate of $\mathrm{N}$ fertilizer use efficiency}

Atom per cent values of ${ }^{15} \mathrm{~N}$ were subtracted from the atom per cent value of atmospheric $N_{2}(0.3663 \%)$ to obtain the atom per cent excess value for the subsequent calculation of the fraction of $\mathrm{N}$ derived from fertilizer $\left(\%_{0} \mathrm{~N}_{u f f}\right)$ and the $\mathrm{N}$ fertilizer use efficiency (NFUE), as indicated below:

$$
\begin{aligned}
& \% N_{\mathrm{drl}}=\left(A E_{\text {plumt }} / A E_{\text {terilizer }}\right) \times 100 \\
& N_{d i f}=N_{\text {tot }} \times \sigma_{0} N_{d r f} / 100 \\
& N F U E=\left(N_{d f f} / N_{\text {appl }}\right) \times 100
\end{aligned}
$$

where $\mathrm{AE}_{\text {plant }}$ is the ${ }^{15} \mathrm{~N}$ atom per cent excess in the plant, $\mathrm{AE}$ fertilizer is the $N$ atom per cent excess in the fertilizer, $N_{\text {tot }}$ is the total $\mathrm{N}$ in the plant ( $\mathrm{kg}$ ha $\left.{ }^{1}\right), \mathrm{N}_{\mathrm{dft}}$ is the fertilizer-derived $\mathrm{N}$ in the plant ( $\mathrm{kg}$ ha ${ }^{1}$ ), and $\mathrm{N}_{\text {anpl }}$ is the $\mathrm{N}$ applied to the plant ( $\mathrm{kg}$ ha ${ }^{1}$ ).

\section{Estimate of $\mathrm{N}_{2}$ fixation in pigeonpea}

The natural abundance in the sample was expressed as a per mil deviation from that of the atmospheric $\mathrm{N}_{2}$ (standard) as follows:

$$
\delta^{15} \mathrm{~N} \text { (per mil) }=\left(\mathbf{R}_{\text {sample }} / \mathbf{R}_{\text {arr }}-1\right) \times 1000
$$

where $R$ is the ${ }^{15} \mathrm{~N}:{ }^{14} \mathrm{~N}$ ratio. The fractional contribution of fixed $\mathrm{N}$ derived from air $\left(\% \mathrm{~N}_{\mathrm{dfa}}\right)$ in pigeonpea plants was calculated using the $\delta^{15} \mathrm{~N}$ value in the following equation:

$$
\% N_{d f a}=\left(\delta^{15} N_{s}-\delta^{15} N_{p}\right) /\left(\delta^{15} N_{s}-\delta^{15} N_{a}\right) \times 100
$$

where $\delta^{15} \mathrm{~N}$, and $\delta^{15} \mathrm{~N}_{\mathrm{p}}$ are the $\delta^{15} \mathrm{~N}$ values for sorghum and pigeonpea, respectively, and $\delta^{15} \mathrm{~N}_{\mathrm{a}}$ is the value for the pigeonpea crop that was solely dependent on atmospheric $\mathrm{N}_{2}$. The amount of $\mathrm{N}$ symbiotically fixed by pigeonpea $\left(\mathrm{N}_{\mathrm{dfa}}, \mathrm{kg} \mathrm{ha}^{-i}\right)$ was calculated as follows:

$$
N_{d f a}=N_{t o r-p} \times \% N_{d f a} / 100
$$

where $N_{\text {tor.p }}$ is the total $N$ accumulated in pigeonpea plants $\left(\mathrm{kg} \mathrm{ha}^{-1}\right)$. For the above two estimates, grain data were used, as this is the major $\mathbf{N}$ storage organ at the time of harvest. 
Statistical analysis

Analysis of variance was performed separately for each crop in order to detect the effect of $\mathrm{N}$ application and of intercropping system on growth, grain yield, and $\mathrm{N}$ yield.

\section{Results}

Growth and yield

The total dry matter and grain yield at maturity for each species are presented in Table 1. The basal application of $\mathrm{N}$ increased both parameters for sorghum, while cropping system had a significant effect only on the total dry matter. The interactive effect of $\mathrm{N}$ application and cropping system was not found on the total dry matter and grain yield of sorghum because both sole and intercropped sorghum reached maximal total dry matter and grain yields at 50 or $100 \mathrm{~kg} \mathrm{~N}$ ha ''. Pigeonpea showed a negligible response to $\mathrm{N}$ application but was significantly affected by cropping systems $(P<0.001$ for total dry matter and $P<0.05$ for grain yield). Although the interaction between $\mathrm{N}$ application and cropping system was insignificant, the sole-cropped pigeonpea had a higher total dry matter and grain yield at 50 and 100 than at 0 and $25 \mathrm{~kg} \mathrm{~N}$ ha '. In the intercropping, however, the pigeonpea had a lower total dry matter and grain yield at 50 and 100 than at 0 and $25 \mathrm{~kg} \mathrm{~N}$ ha'.

\section{Land equivalent ratio and area-time equivalent ratio}

Land equivalent and area-time ratios were calculated for total dry matter and grain yield (Table 2). Both indices invariably exceeded 1 , indicating considerable advantages for the intercropping system. Due to the difference in growth duration between the crops, the area-time ratio was consistently lower than the corresponding land equivalent ratio. Both ratios were greater in treatments with 0 and $25 \mathrm{~kg} \mathrm{~N} \mathrm{ha}^{-1}$ than with 50 and $100 \mathrm{~kg} \mathrm{~N} \mathrm{ha}^{-1}$, with maxima at $25 \mathrm{~kg} \mathrm{~N}$ ha $^{-1}$.

\section{$\mathrm{N}$ yield}

The $\mathrm{N}$ concentration was averaged for all parts of the crop in each treatment. As shown in Table 3, the $\mathrm{N}$ concentration in the sorghum plants at harvest was not altered by the level of $\mathrm{N}$ application or the cropping system. No interactive effect between $\mathrm{N}$ application and cropping system was found for the $\mathrm{N}$ concentration. The total $\mathrm{N}$ yield of sorghum was significantly increased by $\mathrm{N}$ application, following the same trend as total dry matter (Table 1). There was, however, no significant difference in the effect of the cropping system on $\mathrm{N}$ yield.

In evaluating the total $\mathbf{N}$ yield of pigeonpeas, fallen leaves, which amounted to 2.5 and $1.5 \mathrm{t} \mathrm{ha}^{-1}$ on average for the sole crop and the intercrop, respectively, should be
Table 1 Total dry matter and grain yield ( $\mathrm{kg} \mathrm{ha}^{-1}$ ) of sorghum and pigeonpea in sole crop and intercrop at harvest (NO N2S NSO $N / 000,25,50,100 \mathrm{~kg} \mathrm{~N}$ ha ', respectively; $N$ nitrogen treatment, CS cropping system). $* P<0.05 . * P<0.01, * * P<0.001$

\begin{tabular}{|c|c|c|c|c|}
\hline \multirow[t]{2}{*}{ Treatments } & \multicolumn{2}{|l|}{ Sorghum } & \multicolumn{2}{|l|}{ Pigeonpea } \\
\hline & $\begin{array}{l}\text { Total dry } \\
\text { matter }\end{array}$ & Graits yield & $\begin{array}{l}\text { Total dry } \\
\text { matter }\end{array}$ & Grain yield \\
\hline \multicolumn{5}{|l|}{ Sole crop } \\
\hline No & 5290 & 600 & 10770 & 2080 \\
\hline N25 & 6690 & 1330 & 10460 & 2150 \\
\hline NSO & 11460 & 3460 & 13000 & 2300 \\
\hline $\mathrm{N} 100$ & 11510 & $38(x)$ & 12860 & 2170 \\
\hline \multicolumn{5}{|l|}{ Intercrop } \\
\hline No & 3750 & 490 & 7530 & 1690 \\
\hline N25 & 6450 & 1500 & 7660 & 1620 \\
\hline N50 & 8670 & 3030 & 7270 & 1560 \\
\hline$N \mid(0)$ & 8920 & 2980 & 6790 & 1450 \\
\hline \multicolumn{5}{|c|}{ Coefficeints of variation $(\%)$} \\
\hline $\mathrm{N}$ & 11.3 & 16.7 & 20.4 & 21.3 \\
\hline C'S & 10.0 & 16.0 & 14.4 & 20.3 \\
\hline \multicolumn{5}{|c|}{ Stutistical significance } \\
\hline $\mathbf{N}$ & $\ldots$ & *** & NS & NS \\
\hline CS & $* * *$ & NS & $* * *$ & * \\
\hline $\mathrm{N} \times \mathrm{CS}$ & NS & NS & NS & NS \\
\hline
\end{tabular}

considered because the abscission of lower leaves under the thick canopy is an inherent trait of medium-duration pigeonpeas. The concentration of $\mathrm{N}$ in intercropped pigeonpea plants was higher than that in the sole-cropped plants. Nonetheless, the total $\mathrm{N}$ yield of the pigeonpea was decreased by intercropping because of the significant reduction in dry matter yield.

\section{Fertilizer use efficiency}

The ${ }^{15} \mathrm{~N}$-labeling method was used to estimate fractional contribution of $\mathrm{N}$ derived from fertilizer $\left(\% \mathrm{~N}_{\mathrm{drf}}\right)$ (Table

Table 2 Relative yield of intercropped (compared to sole crop yield) sorghum and pigeonpea, and land equivalent ratio (LER) and area-time equivalent ratio (ATER) estimated for total dry matter and grain yield (see Table 1 for explanation of $N$ treatment)

\begin{tabular}{lllll}
\hline N treatment & \multicolumn{2}{l}{ Relative yield } & LER & ATER \\
\cline { 2 - 3 } & Sorghum & Pigeonpea & & \\
\hline Total dry matter & & & & \\
N0 & 0.71 & 0.70 & 1.41 & 1.09 \\
N25 & 0.96 & 0.73 & 1.70 & 1.26 \\
N50 & 0.76 & 0.56 & 1.32 & 0.98 \\
N100 & 0.78 & 0.53 & 1.30 & 0.95 \\
Grain yield & & & & \\
N0 & 0.80 & 0.81 & 1.62 & 1.25 \\
N25 & 1.13 & 0.75 & 1.88 & 1.37 \\
N50 & 0.88 & 0.68 & 1.56 & 1.16 \\
N100 & 0.78 & 0.67 & 1.45 & 1.10 \\
\hline
\end{tabular}


Table $3 \mathrm{~N}$ concentration $(\%)$ and $\mathrm{N}$ yield $\left(\mathrm{kg} \mathrm{ha}^{-1}\right)$ of sorghum and pigeonpea in sole crop and intercrop at harvest (see Table I for further explanations)

\begin{tabular}{|c|c|c|c|c|c|}
\hline \multirow[t]{2}{*}{ Treatments } & \multicolumn{2}{|c|}{ Sorghum } & \multicolumn{3}{|c|}{ Pigeonpea } \\
\hline & Conc." & Yield ${ }^{b}$ & Conc." & Yield $^{b}$ & $\begin{array}{l}\text { Fallen } \\
\text { leaves }\end{array}$ \\
\hline Sole crop & & & & & \\
\hline $\begin{array}{l}\text { N0 } \\
\text { N25 } \\
\text { N50 } \\
\text { N100 }\end{array}$ & $\begin{array}{l}0.64 \\
0.60 \\
0.61 \\
0.77\end{array}$ & $\begin{array}{l}28.3 \\
35.6 \\
57.7 \\
73.8\end{array}$ & $\begin{array}{l}2.20 \\
2.18 \\
2.15 \\
2.19\end{array}$ & $\begin{array}{l}217.3 \\
209.6 \\
254.3 \\
253.8\end{array}$ & $\begin{array}{l}23.6 \\
29.2 \\
32.2 \\
24.7\end{array}$ \\
\hline $\begin{array}{l}\text { Intercrop } \\
\text { N0 } \\
\text { N25 } \\
\text { N50 } \\
\text { N100 }\end{array}$ & $\begin{array}{l}0.65 \\
0.65 \\
0.73 \\
0.79\end{array}$ & $\begin{array}{l}20.1 \\
36.7 \\
57.2 \\
62.6\end{array}$ & $\begin{array}{l}2.45 \\
2.43 \\
2.32 \\
2.42\end{array}$ & $\begin{array}{l}171.7 \\
171.2 \\
158.4 \\
151.1\end{array}$ & $\begin{array}{l}17.7 \\
15.0 \\
15.6 \\
11.8\end{array}$ \\
\hline $\begin{array}{l}\text { Coefficients } \\
\mathbf{N} \\
\mathrm{CS}\end{array}$ & $\begin{array}{c}f \text { variatio } \\
14.3 \\
9.0\end{array}$ & $\begin{array}{l}(\%) \\
19.1 \\
18.3\end{array}$ & $\begin{array}{l}9.0 \\
\text { R. } 8\end{array}$ & $\begin{array}{l}18.4 \\
18.7\end{array}$ & $\begin{array}{l}24.5 \\
17.4\end{array}$ \\
\hline $\begin{array}{l}\text { Statistical sig } \\
\mathrm{N} \\
\mathrm{CS} \\
\mathrm{N} \times \mathrm{CS}\end{array}$ & $\begin{array}{l}\text { ificance } \\
\text { NS } \\
\text { NS } \\
\text { NS }\end{array}$ & $\begin{array}{l}* * * \\
\text { NS } \\
\text { NS }\end{array}$ & $\begin{array}{l}\text { NS } \\
\text { NS }\end{array}$ & $\begin{array}{l}\text { NS } \\
\text { NS }\end{array}$ & $\begin{array}{l}\text { NS } \\
\text { NS }\end{array}$ \\
\hline
\end{tabular}

- Average $\mathbf{N}$ concentration in whole plants except fallen leaves

- $\mathrm{N}$ yield by whole plant parts except fallen leaves

' $\mathrm{N}$ conient of fallen leaves of pigeonpea

4). Because most of the $N(50 \%$ in sorghum and $75 \%$ in pigeonpea, on average) was distributed in the grain at harvest and the ${ }^{15} \mathrm{~N}$ enrichment in other parts of the plant was almost similar to that in the grain, data for grain $\mathrm{N}$ was used to estimate the percentage of $\mathrm{N}$ derived from fertilizer. For both crops, this value increased with the level of $\mathrm{N}$ fertilizer because it was directly proportional to the measured atom per cent excess value. However, the per cent $\mathbf{N}$ derived from fertilizer was much greater in the sorghum than in the pigeonpea, clearly demonstrating the higher dependency on fertilizer $\mathrm{N}$ in the non-leguminous plant. The per cent $\mathbf{N}$ derived from fertilizer by sorghum plants was not changed by the cropping system; however, a significant decrease was observed in the pigeonpea. It is assumed that in an intercropping system, competition for the uptake of fertilizer $\mathbf{N}$ is severe between the component crops, and sorghum plants are likely to be superior to pigeonpea plants in their ability to take up $\mathbf{N}$ applied as fertilizer. This assumption is confirmed by the data on the amount of plant $\mathbf{N}$ derived from fertilizer. In the intercropping system, sorghum plants absorbed more fertilizer $\mathrm{N}$ than the pigeonpea on a unit area basis.

The fertilizer use efficiency was consistently higher in sorghum than in pigeonpea plants when intercropped. In sole cropping, however, no consistent trend was observed. In both crops, the fertilizer use efficiency appeared to increase with $\mathrm{N}$ application, although this was not statistically significant.

\section{$\mathrm{N}_{2}$ fixation by pigeonpea}

The natural abundance $\left(\delta^{15} \mathrm{~N}\right)$ values in sorghum grain showed relatively less variation among replications than those of pigeonpea (Table 5). The same trend was observed in other parts of the plants that were analyzed (data not shown). The $\delta^{15} \mathrm{~N}$ for sorghum grown in unfertilized soil was a little below +5.0 per mil, which was close to the value of total (Kjeldahl-digested) soil $\mathrm{N}$ found in the experimental field before sowing. Because of the contribution from $\mathrm{N}_{2}$ fixation, $\delta^{15} \mathrm{~N}$ values were consistently lower in the pigeonpea than in the sorghum. The pigeonpea value decreased dramatically with sorghum intercropping, whereas that of sorghum increased except when no $\mathrm{N}$ fertilizer was applied. When grown in $\mathrm{N}$-free medium, pigeonpea plants (cv ICPL 87) averaged $-1.59 \pm 0.44$ per mil for the natural ${ }^{15} \mathrm{~N}$ abundance in shoots. This was used as the $\delta^{15} \mathrm{~N}_{\mathrm{a}}$ value in the present study.

Symbiotic $\mathrm{N}_{2}$ fixation by the pigeonpea was estimated from the values of $\delta^{15} \mathrm{~N}$ in grain (reasons given in previ-
Table 4 Fractional contribution $\left(\% \mathrm{~N}_{\mathrm{dft}}\right)$ and amount $\left(\mathrm{N}_{\mathrm{dff}}\right)$ of plant $\mathrm{N}$ derived from fertilizer, and fertilizer use efficiency $(F \cup E)$ of sorghum and pigeonpea, calculated with atom per cent excess values. measured in grain (see Table 1 for further explanations)

\begin{tabular}{|c|c|c|c|c|c|c|c|c|}
\hline \multirow[t]{2}{*}{ Treatments } & \multicolumn{4}{|l|}{ Sorghum } & \multicolumn{4}{|l|}{ Pigeonpea } \\
\hline & $\begin{array}{l}\text { Atom } \% \\
\text { excess }\end{array}$ & $\% \mathrm{~N}_{\mathrm{dfr}}$ & $\begin{array}{l}\mathbf{N}_{\mathrm{dfl}} \\
(\mathrm{kg} h \mathrm{~h} \cdot 1)\end{array}$ & $\begin{array}{l}\text { FUE } \\
(\%)\end{array}$ & $\begin{array}{l}\text { Atom \% } \\
\text { excess }\end{array}$ & $\% 0 \mathrm{~N}_{\text {dif }}$ & $\begin{array}{l}N_{d l f} \\
\left(\mathrm{~kg} \mathrm{ha}^{-1}\right)\end{array}$ & $\begin{array}{l}\text { FUE } \\
(\%)\end{array}$ \\
\hline \multicolumn{9}{|l|}{ Sole crop } \\
\hline N25 & 0.233 & 8.0 & 2.8 & 11.2 & 0.056 & 1.9 & 4.5 & 17.9 \\
\hline N50 & 0.498 & 17.2 & 10.5 & 20.9 & 0.095 & 3.3 & 9.2 & 18.4 \\
\hline N100 & 0.800 & 27.6 & 21.5 & 21.5 & 0.372 & 12.8 & 35.2 & 35.2 \\
\hline \multicolumn{9}{|l|}{ Intercrop } \\
\hline N25 & 0.287 & 9.9 & 3.7 & 14.7 & 0.015 & 0.5 & 1.0 & 4.0 \\
\hline N50 & 0.512 & 17.7 & 10.5 & 21.0 & 0.031 & 1.1 & 1.9 & 3.8 \\
\hline N100 & 0.930 & 32.1 & 20.5 & 20.5 & 0.070 & 2.4 & 3.5 & 3.5 \\
\hline \multicolumn{9}{|c|}{ Coefficients of variations (\%) } \\
\hline $\mathrm{N}$ & - & 10.3 & 35.3 & 24.9 & - & 58.2 & 63.9 & 51.8 \\
\hline CS & - & 31.1 & 34.0 & 27.2 & - & 60.2 & 72.4 & 59.7 \\
\hline \multicolumn{9}{|c|}{ Statistical significance } \\
\hline $\mathrm{N}$ & - & $* *$ & $*$ & NS & - & • & $\omega$ & NS \\
\hline CS & - & NS & NS & NS & - & $* *$ & $\omega$ & $* *$ \\
\hline $\mathrm{N} \times \mathrm{CS}$ & - & NS & NS & NS & - & - & $\bullet$ & NS \\
\hline
\end{tabular}


Table 5 Fractional contribution $\left(\% \mathrm{~N}_{\mathrm{dfa}}\right)$ and $\left(\mathrm{N}_{\mathrm{df}}\right)$ amount of $\mathrm{N}$ derived from air in pigeonpea, calculated with $\delta^{\circ} \mathrm{N}$ values measured in grain (see Table $I$ for further expalanations)

\begin{tabular}{|c|c|c|c|c|}
\hline \multirow[t]{2}{*}{ Treatment } & \multicolumn{2}{|l|}{$\delta^{15} \mathrm{~N}$ value } & \multirow[t]{2}{*}{$\sigma_{0} \mathrm{~N}_{\mathrm{df}}$} & \multirow{2}{*}{$\begin{array}{l}\mathrm{N}_{\mathrm{dfa}} \\
(\mathrm{kg} \text { ha } \\
\end{array}$} \\
\hline & Sorghum & Pigeonpea & & \\
\hline $\begin{array}{l}\text { Sole crop } \\
\text { N0 } \\
\text { N25 } \\
\text { N50 } \\
\text { N100 } \\
\text { Intercrop }\end{array}$ & $\begin{array}{l}+3.86(0.24)^{a} \\
+2.71(0.26) \\
+2.79(0.46) \\
+2.87(0.27)\end{array}$ & $\begin{array}{l}+0.46(0.96) \\
+0.63(0.68) \\
+0.12(0.79) \\
+0.19(0.18)\end{array}$ & $\begin{array}{l}63.0 \\
49.0 \\
61.3 \\
43.7\end{array}$ & $\begin{array}{l}150.1 \\
122.9 \\
170.5 \\
123.5\end{array}$ \\
\hline $\begin{array}{l}\text { N0 } \\
\text { N25 } \\
\text { N50 } \\
\text { N100 }\end{array}$ & $\begin{array}{l}+3.48(0.42) \\
+3.17(0.73) \\
+3.13(0.53) \\
+3.36(0.35)\end{array}$ & $\begin{array}{l}-0.82(0.76) \\
-0.92(0.46) \\
-0.43(0.64) \\
+0.50(0.75)\end{array}$ & $\begin{array}{l}86.0 \\
84.1 \\
76.7 \\
65.4\end{array}$ & $\begin{array}{l}165.7 \\
165.4 \\
134.1 \\
129.5\end{array}$ \\
\hline $\begin{array}{l}\text { Coefficient: } \\
\mathbf{N} \\
\mathrm{CS}\end{array}$ & 5 of variation (\% & - & $\begin{array}{l}25.2 \\
21.3\end{array}$ & $\begin{array}{l}27.9 \\
24.1\end{array}$ \\
\hline $\begin{array}{l}\text { Statistical s } \\
\mathrm{N} \\
\mathrm{CS} \\
\mathrm{N} \times \mathrm{CS}\end{array}$ & $\begin{array}{l}\text { ignificance } \\
\text { NS } \\
\text { NS } \\
\text { NS }\end{array}$ & $\begin{array}{l}\text { NS } \\
\text { NS }\end{array}$ & $\begin{array}{l}\text { NS } \\
\text { NS }\end{array}$ & $\begin{array}{l}\text { NS } \\
\text { NS } \\
\text { NS }\end{array}$ \\
\hline
\end{tabular}

a Standard deviation among replications for each treatment

ous section), using the sorghum plants as a reference. The fractional contribution of $\mathrm{N}$ derived from air was affected by both the $\mathrm{N}$ application and the cropping system (Table 5). Less $\mathrm{N}$ fertilizer and an intercropping environment raised the contribution. In sole-cropped pigeonpea, $50-60 \%$ of $\mathrm{N}$ came from air, whereas $65-85 \%$ of $\mathrm{N}$ in the plant was derived from atmospheric $\mathrm{N}$ when intercropped. Due to the large variation in $\mathbf{N}$ derived from air among replicates, the effect of fertilizer on this parameter was not statistically significant.

Although intercropping appeared to force the pigeonpea plants to depend more upon atmospheric $\mathrm{N}$, the actual amount of $\mathrm{N}$ fixed symbiotically by the plant was not significantly increased by intercropping (Table 5). This was obviously due to the decrease in dry matter production and, consequently, lower total $\mathrm{N}$ content of the intercropped than the sole-cropped pigeonpea (Table 3). No statistically significant difference was observed in the effect of fertilizer $\mathrm{N}$, though $\mathrm{N}$ application tended to reduce the $\mathrm{N}$ derived from air. As a whole, pigeonpea fixed $120-170 \mathrm{~kg} \mathrm{ha}^{-1}$ of atmospheric $\mathrm{N}$ throughout the cropping season, regardless of either the level of basal fertilization or the cropping system.

\section{$\mathrm{N}$ budget}

The fractional contribution of $\mathrm{N}$ derived from soil was calculated from the values for $\mathrm{N}$ derived from fertilizer and from air, and the total quantity of $\mathrm{N}$ derived from soil by the crops was evaluated. Then the entire $\mathrm{N}$ budged within the crops was calculated to compare the sole and intercropping systems (Table 6). Figure 1 shows the amount of $\mathrm{N}$ taken up by the individual crops from three different sources, soil, fertilizer, and atmosphere, in sole cropping and intercropping with four levels of fertilizer $\mathrm{N}$ application. This presentation clearly shows that the assimilation of soil $\mathrm{N}$ and fertilizer $\mathrm{N}$ by the pigeonpea was almost the same as that by the sorghum in the sole cropping system, which indicates the potential competence of pigeonpeas to exploit $\mathrm{N}$ in soil. However, when $\mathrm{N}$ is exhausted by an intercrop, and by leaching and immobilization, the pigeonpea increases its dependency on atmospheric $\mathrm{N}_{2}$ fixation. A proper allocation of $\mathrm{N}$ from different sources between the component crops is an important consideration in maximizing the efficiency of $\mathrm{N}$ use in intercropping systems.

\section{Discussion}

\section{Growth and yield}

Sorghum/pigeonpea intercropping system is a common combination among cropping systems in the Indian subcontinent. The present study is focused on the $\mathrm{N}$ economy of the cropping system, involving fertilizer use and $\mathrm{N}$ fixation, for which very little information has so far been made available.

Table $6 \mathrm{~N}$ sources and whole budget $\left(\mathrm{kg} \mathrm{ha}^{-1}\right)$ of sorghum and pigeonpea in sole crop and intercrop (means \pm SEM, see Table 1 for explanation for treatment)

\begin{tabular}{|c|c|c|c|c|c|c|c|}
\hline \multirow[t]{2}{*}{ Treatment } & \multicolumn{3}{|l|}{ Sorghum } & \multicolumn{4}{|l|}{ Pigeonpea } \\
\hline & Fertilizer & Soil & Whole budget & Air & Fertilizer & Soil & Whole budget \\
\hline \multicolumn{8}{|l|}{ Sole crop } \\
\hline $\begin{array}{l}\text { N0 } \\
\text { N25 } \\
\text { N50 } \\
\text { N100 } \\
\text { Intercrop }\end{array}$ & $\begin{array}{l}0 \\
2.8 \pm 0.8 \\
10.5 \pm 1.9 \\
21.5 \pm 5.0\end{array}$ & $\begin{array}{l}28.3 \pm 2.2 \\
32.8 \pm 9.9 \\
49.9 \pm 4.5 \\
57.1 \pm 11.7\end{array}$ & $\begin{array}{l}28.3 \pm 2.2 \\
35.6 \pm 10.6 \\
61.3 \pm 5.4 \\
78.6 \pm 13.7\end{array}$ & $\begin{array}{l}150.1 \pm 35.6 \\
122.9 \pm 51.5 \\
170.5 \pm 34.7 \\
123.5 \pm 30.3\end{array}$ & $\begin{array}{r}0 \\
4.9 \pm 0.5 \\
9.2 \pm 4.8 \\
35.2 \pm 12.3\end{array}$ & $\begin{array}{r}90.8 \pm 44.1 \\
111.3 \pm 10.4 \\
106.8 \pm 62.9 \\
119.8 \pm 26.8\end{array}$ & $\begin{array}{l}240.8 \pm 19.2 \\
238.8 \pm 42.9 \\
286.5 \pm 32.6 \\
278.5 \pm 42.1\end{array}$ \\
\hline $\begin{array}{l}\text { No } \\
\text { N25 } \\
\text { N50 } \\
\text { N100 }\end{array}$ & $\begin{array}{l}0 \\
3.7 \pm 0.9 \\
10.5 \pm 1.5 \\
20.5 \pm 6.1\end{array}$ & $\begin{array}{l}20.1 \pm 4.1 \\
33.0 \pm 3.7 \\
49.7 \pm 11.1 \\
42.2 \pm 6.9\end{array}$ & $\begin{array}{l}20.1 \pm 4.1 \\
36.7 \pm 4.4 \\
57.2 \pm 11.1 \\
62.6 \pm 11.9\end{array}$ & $\begin{array}{l}165.7 \pm 41.8 \\
156.4 \pm 22.3 \\
134.1 \pm 40.0 \\
129.5 \pm 53.8\end{array}$ & $\begin{array}{l}0 \\
1.0 \pm 0.6 \\
1.9 \pm 0.9 \\
3.5 \pm 0.3\end{array}$ & $\begin{array}{l}23.6 \pm 19.7 \\
28.8 \pm 21.9 \\
38.0 \pm 19.5 \\
59.4 \pm 6.3\end{array}$ & $\begin{array}{l}189.3 \pm 22.1 \\
186.2 \pm 9.6 \\
174.0 \pm 46.6 \\
162.9 \pm 53.6\end{array}$ \\
\hline
\end{tabular}


Fig. 1 Diagragmatic representation of $\mathrm{N}$ budget in sor. ghum and pigeonpea in sole cropping (Sole) and intercrop. ping (Inter) at four levels of fertilizer $\mathrm{N}$ application $(0,25$, 50 , and $100 \mathrm{~kg}$ ha '). The size of each square is proportional to amount of $\mathrm{N}$ taken up by plants. The squares with 1, 5 , 25 and $125 \mathrm{~kg}$ ha 'are given in an inset for semi-quantification. $A, F, S, \mathrm{~N}$ from atmo. sphere, fertilizer, and soil. respectively

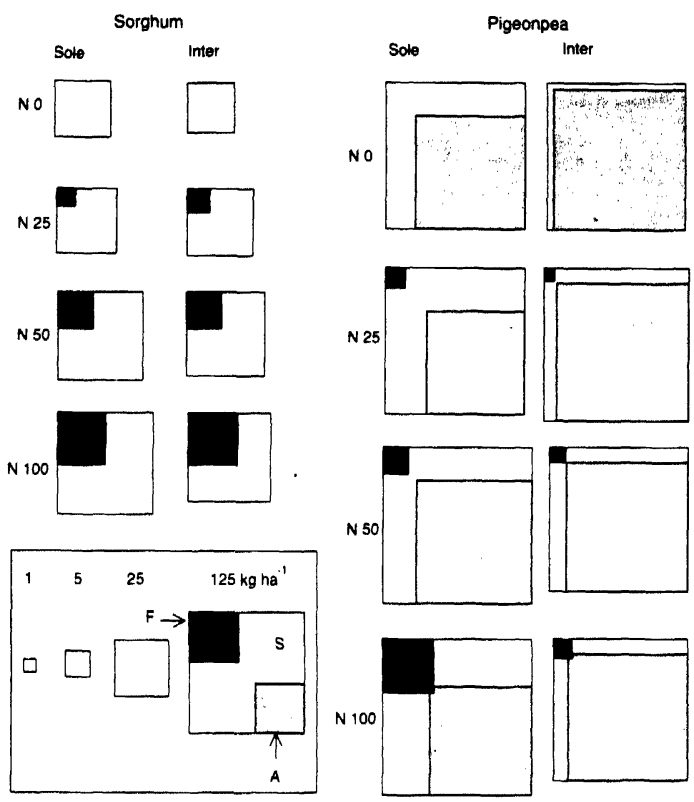

The total dry weight and grain yield at harvesting time were lower in intercrops than in sole crops for both components of the system (Table 1). This indicates that the component crops compete with each other for the limited amount of resources under the intercropping condition. Previously, Natarajan and Willey (1980) suggested that competition above the ground was severe between sorghum and pigeonpeas when intercropped, in terms of light interception as one of the resources used. In our present results, competition was more prominent in soil supplied with higher amounts of $\mathrm{N}$, and the land equivalent and area-time equivalent ratios were lower with 50 and $100 \mathrm{~kg} \mathrm{~N} \mathrm{ha}^{-1}$ than with 0 and $25 \mathrm{~kg} \mathrm{ha}^{-1}$ (Table 2). This may have been caused by the greater reduction in the relative yield of pigeonpea $\left(Y_{\mathrm{ps}} / Y_{\mathrm{pp}}\right.$, Table 2$)$ at high levels of fertilizer $N$. The highest land equivalent and areatime equivalent ratios, recorded at $25 \mathrm{~kg} \mathrm{~N} \mathrm{ha}^{-1}$ appear to have been a result of the smaller reduction in sorghum yield under intercropping. Sorghum showed a clear response to $\mathbf{N}$ fertilizer, while pigeonpea growth and yield were unaltered (Table 1). The more vigorous growth of sorghum with increasing fertilizer $\mathrm{N}$ applications might have induced an unfavorable environment, such as less water and light for the associated pigeonpea, resulting in the lower relative yield at higher rates of fertilizer $\mathrm{N}$ application. However, it is extremely difficult to explain these differences in the land equivalent and area-time equivalent ratios from results pertaining to the $\mathrm{N}$ economy of the intercropping system.

\section{Use of fertilizer $\mathrm{N}$}

The total dry matter and grain yields of component crops were generally lower in intercropping than in sole cropping (Table 1). This indicates that the component crops compete for limited resources under the intercropped condition. Considerable competition between sorghum and pigeonpea has already been demonstrated in terms of light interception (Natarajan and Willey 1980), but there is little evidence available on the extent of competition for fertilizer $\mathrm{N}$. Competition for soil $\mathrm{N}$ between intercropped cowpea and maize has been reported by Chang and Shibles (1985) and Ofori and Stern (1986), who conducted experiments in unfertilized fields to simplify the experiment. In the present study the sum of the fertilizer up- 
al. 1986), most reports have been based on results from pot experiments. In the present experiment, we compared $\delta^{15} \mathrm{~N}$ values for sorghum between sole crops and intercrops. If $\mathrm{N}$ had been transferred, the value for intercropped sorghum would have been reduced by dilution with atmospheric $\mathrm{N}$, giving a $\delta^{15} \mathrm{~N}_{\mathrm{a}}$ value. However, that was not the case (Table 5), indicating that direct and immediate $\mathrm{N}$ transfer from pigeonpea to sorghum was insignificant in the field. It is also evident from our study (Table 1) that both sole and intercropped sorghum responded similarly to fertilizer $\mathbf{N}$ in terms of dry matter production and grain yield, as previously reported by Rego (1981). Moreover, there was no significant difference in $\mathrm{N}$ concentrations in sorghum between the two cropping systems (Table 3), providing further indirect evidence that very little $\mathrm{N}$ was transferred in the field.

Acknowledgements We thank Dr. T. Murakami, Tropical Agriculture Research Center, Japan, for technical assistance and Dr. J.V.D.K. Kumar Rao, ICRISAT Center, for providing the $\delta^{15} \mathrm{~N}_{\text {a }}$ sample of pigeonpea. We thank Dr. J.J. Adu-Gyamfi for critical comments on the manuscript.

\section{References}

Arihara J, Ae N, Okada K (1991) Root development of pigeonpea and chickpea and its significance in different cropping systems. In: Johansen C. Lee KK. Sahrawat KL (eds) Phosphorus nutrition of grain legumes in the semi-arid tropics. ICRISAT, Patancheru, India, pp 183-194

Bandyopadhyay SK, De $R$ (1986) N relationship in a legume nonlegume association grown in an intercropping sysiem. Fertil Res $10: 73-82$

Chalk PM (1985) Estimation of $N_{2}$ fixation by isotopic dilution: an appraisal of techniques involving ${ }^{13} \mathrm{~N}$ enrichment and their application. Soil Biol Biochem 17:183-192

Chang JF, Shibles RM (1985) An analysis of competition between intercropped cowpea and maize (I). Soil $N$ and $P$ levels and their relationships with dry matter and seed productivity. Field Crops Res $12: 133-143$

Chaykin S (1969) Assay of nicotinamide deaminase. Determination of ammonia by the indophenol reaction. Anal Biochem 32:375-382

Danso SKA, Zapata F, Harderson G, Fried M (1987) Nitrogen fixation in fababeans as affected by plant population density in sole or intercropped systems with barley. Soil Biol Biochem 19:411-415

Eaglesham ARJ, Ayanaba A, Ranga Rao V, Eskew DL (1981) Im. proving the nitrogen nutrition of maize by intercropping with cowpea. Soil Biol Biochem 13:169-171

Elmore RW, Jackobs JA (1986) Yieid and nitrogen yield of sorghum intercropped with nodulating and nonnodulating soybeans. Agron J 78:780-782

Hiebsch CK, McCollum RE (1987) Area-time equivalency ratio: A method for evaluating the productivity of intercrops. Agron J 79:15-22

Ito O, Matsunaga R. Tobita S, Rao TP (1991) Rooting behaviour and root activities of intercropped pigeonpea [Cajanus cajan (L.) Millspaugh] and sorghum (Sorghum vulgare L.) as affected by nitrogen fertilization. In Abstracts of the 3rd Symposium of the International Society of Root Research, 2-6 Sept 1991, Vienna, Austria, p 90
Jena D, Misra C (1990) Symbiotic N fixation and fertilizer nitrogen use efficiency in legume-cereal intercropping systems. J Indian Soc Soil Sci 38:667-673

Kumar Rao JVDK, Thompson JA, Sastry PVSS, Giller KE, Day JM (1987) Measurement of $\mathrm{N}_{2}$-fixation in field-grown pigeonpea [Cajanus cajan (L.) Millsp.] using ${ }^{15} \mathrm{~N}$-labelled fertilizer. Plant and Soil 101:107 - 113

La Favre JS, Focht DD (1983) Comparison of $\mathrm{N}_{2}$ fixation and yields in Cajanus cajan between hydrogenase-positive and hydrogenase-negative Rhizobia by in situ acetylene reduction assay and direct $15 \mathrm{~N}$ partitioning. Plan1 Physiol 72:971-977

Mead R, Willey RW (1980) The concept of a 'Land equivalent Ratio' and advantages in yields from intercropping. Exp Agric $16: 217-228$

Natarajan M, Willey RW (1980) Sorghum-pigeonpea intercropping and the effects of plant population density. 11. Resource use. J Agric Sci 95:59-65

Ofori F. Stern WR (1986) Maize/cowpea intercropping system: Effect of nitrogen fertilizer on productivity and efficiency. Field Crops Res 14:247 261

Ofori F, Pate JS, Stern WR (1987) Evaluation of $\mathrm{N}_{2}$-fixation and nitrogen economy of a maize/cowpea intercrop system using ${ }^{15} \mathrm{~N}$ dilution methods. Plant and Soil 102:149-160

Papastylianou I (1988) The ${ }^{15} \mathrm{~N}$ methodology in estimating $\mathrm{N}_{2}$ fixation by vetch and pea grown in pure stand and mixtures with oat. Plant and Soil 107:183-188

Papastylianou 1, Danso SKA (1991) Nitrogen fixation and transfer in vetch and vetch-oat inixtures. Soil Biol Biochem 23:447-452

Patra DD, Sachdev MS, Subbiah BV (1986) ${ }^{15} \mathrm{~N}$ studies on the transfer of legume-fixed nitrogen to associated cereals in intercropping systems. Biol Fertil Soils 2:165-171

Peoples MB, Faizal AW, Rerkasem B, Herridge DF (1989) Methods for evaluating nitrogen fixation by nodulated legumes in the field. Aust Commonw Inst Agric Res, Canberra

Rego TJ (1981) Nitrogen response studies of intercropped sorghum with pigeonpea. In Proceedings of international workshop for intercropping, 10-13 Jan, 1979. ICRISAT, Hyderabad, pp $210-216$

Rerkasem B, Rerkasem K, Peoples MB, Herridge DF, Bergersen FJ (1988) Measurement of $\mathrm{N}_{2}$ fixation in maize (Zea mays L..)-ricebean (Vignia umbellata [Thumb.] Ohwi and Ohashi) intercrops. Plant and Soil 108:125-135

Shearer G, Kohl DH (1986) $\mathrm{N}_{2}$ fixation in field settings: Estimations based on natural ${ }^{15} \mathrm{~N}$ abundance. Aust J Plant Physiol 13:699-756

Singh U, Sahrawat KL, Jambunathan R, Burford JR (1984) The use of hydrogen peroxide for the digestion and determination of total nitrogen in chickpea (Cicer arientinum L.) and pigeonpea (Cajanus cajan L.) J Sci Food Agric 35:640-646

van Kessel C, Roskoski JP (1988) Row spacing effects of $\mathrm{N}_{2}$-fixation, $\mathrm{N}$-yield and soil $\mathrm{N}$ uptake of intercropped cowpea and maize. Plant and Soil 111:17-23

Vose PB, Victoria RL (1986) Re-examination of the limitations of nitrogen-15 isotope dilution technique for the field measurement of dinitrogen fixation. In: Hauck RD, Weaver RW (eds) Field measurement of dinitrogen fixation and denitrification. Soil Sci Soc Am, Madison, Wis, pp 23-41

Willey RW (1979) Intercropping - Its importance and research needs. Part 1. Competition and yield advantages. Field Crop Abstr 32:1-11

Willey RW, Rao MR, Natarajan M (1981) Traditional cropping systems with pigeonpes and their improvement. In: Nene $Y L$, Kumble V (eds) Proceedings of the International Workshop on Pigeonpeas, vol 1. ICRISAT, Patancheru, pp 11-25

Yoneyama T (1987) $\mathrm{N}_{2}$-fixation and natural ${ }^{15} \mathrm{~N}$ abundance of leguminous plants and Azolla. Bull Natl Inst Agrobiol Resour 3:59-87

Yoneyama T, Nambiar PTC, Lee KK, Srinivasa Rao B, Williams JH (1990) Nitrogen accumulation in three legumes and two cereals with emphasis on estimation of $\mathrm{N}_{2}$ fixation in the legumes by the natural ${ }^{15} \mathrm{~N}$-abundance technique. Biol Fertil Soils 9:25-30 
take by the intercrop $\left(4.7,12.3\right.$, and $24.0 \mathrm{~kg} \mathrm{ha}^{-1}$ for 25 , 50 , and $100 \mathrm{~kg} \mathrm{Nha}^{-1}$, respectively) was less than the sum for each sole crop $\left(7.3,19.7\right.$, and $\left.56.7 \mathrm{~kg} \mathrm{ha}^{-1}\right)$ as shown in Table 3. The pigeonpea derived much less $\mathbf{N}$ from fertilizer in the intercropped condition, whereas in sorghum, the values were retained. A greater uptake of $\mathrm{N}$ from fertilizer by the intercropped sorghum than the intercropped pigeonpea indicates the superiority of the cereal over the legume in exploiting soil N. A greater reduction in the total dry matter and the grain yield was observed in pigeonpea than in sorghum (Tables 1,2 ), which may have been due in part to the competition for fertilizer $\mathrm{N}$ in the rhizosphere.

The $\mathrm{N}$ fertilizer use efficiency was generally low in this particular experiment (Table 4). One reason was apparent from the level of inorganic $N$ in soil solution collected from the same experimental field (data not shown). Most of the soil $\mathrm{NO}_{3}$ had already been leached out from the rooting zone or immobilized into soil by 60 days after sowing. The higher $\mathbf{N}$ fertilizer use efficiency in the sole pigeonpea than in the sole sorghum may have been the result of deeper development of pigeonpea roots (Arihara et al. 1991). However, in the intercropping condition, the sorghum plants may have absorbed the fertilizer $\mathrm{N}$ more rapidly than the slow-growing pigeonpea, resulting in less $\mathrm{N}$ available to the pigeonpea. A similar result was reported for the intercropping systems of rice/pigeonpea and finger millet/pigeonpea (Jena and Misra 1990). Therefore, more effective methods of fertilizer application should be considered to increase $\mathrm{N}$ fertilizer use efficiency in intercropping, particularly with regard to the timing and placement of fertilizer and use of a slow-release fertilizer. This is especially important for cropping systems in the semi-arid tropics where leaching of mineral $\mathrm{N}$ is intensive.

\section{$\mathrm{N}$ fixation}

As Chalk (1985) and Vose and Victoria (1986) described, the ${ }^{15} \mathrm{~N}$ dilution method has limited applicability in estimating $\mathrm{N}_{2}$ fixation. In principle, reference plants must take up $\mathrm{N}$ at the same ratio of soil $\mathrm{N}$ to fertilizer $\mathrm{N}$ as the target legumes do. When applying the method to cereal/legume intercropping systems, this prerequisite is thought to restrict the combination of crops that can be studied. Crops that have large differences in rooting pattern and/or growth duration are commonly combined together in intercropping. Larger differences in root growth and morphology between the intercrop components have already been reported (Ito et al. 1991). Moreover, the cropping durations were considerably different ( 110 days for sorghum and 200 days for pigeonpea). In the present experiment, therefore, the natural ${ }^{15} \mathrm{~N}$ abundance technique was used for quantitative estimates of $\mathrm{N}_{2}$ fixation.

Additional consideration is required when the natural ${ }^{15} \mathrm{~N}$ abundance method is used to estimate $\mathrm{N}_{2}$ fixation by a long-duration legume using a short-duration reference, as in the present experiment. Shearer and Kohl (1986) argued that the validity of a reference plant might be a less serious problem for the natural abundance method than for other isotope dilution methods, at least with respect to the variation in soil available $\mathrm{N}$ during the growing season. Field observations at the ICRISAT Center have shown that $\delta^{15} \mathrm{~N}$ values remained relatively constant in both nodulating and non-nodulating groundnut plants over the growing season (Yoneyama et al. 1990). When these factors are taken into consideration, the combination of ${ }^{15} \mathrm{~N}$ labeling technique and natural ${ }^{15} \mathrm{~N}$ abundance method appears to be an appropriate for obtaining $\mathrm{N}$ budgets in cereal/legume intercropping systems.

The $\delta^{15} \mathrm{~N}$ value in shoots of pigeonpea plants dependent solely on atmospheric $\mathrm{N}_{2}$ for $\mathrm{N}$ supplies was estimated to be -1.59 per mill, which was almost consistent with a previously reported $\delta^{15} \mathrm{~N}_{\mathrm{a}}$ value for Cajanus cajan (Peoples et al. 1989) and for soybean (Yoneyama 1987). In the pigeonpea, the fractional contribution of $\mathrm{N}$ derived from air was significantly greater for the intercrop $(65-85 \%)$ than the sole crop $(45-65 \%)$. The natural abundance technique has also given a similar result in a maize/cowpea intercropping system (Rerkasem et al. 1988). With the ${ }^{15} \mathrm{~N}$-labeling technique, significantly higher values for $\mathrm{N}$ derived from air by the intercrop compared to the sole crop have been reported with cowpea (van Kessel and Roskoski 1988), faba beans (Danso et al. 1987), and peas (Papastylianou 1988).

In the present study, the per cent $\mathrm{N}$ derived from air by the pigeonpea seemed to be reduced by applications of basal $\mathrm{N}$ regardless of cropping patterns, although the trend was not statistically significant (Table 5). Jena and Misra (1990) reported a similar but clearer tendency in rice/pigeonpea intercropping systems.

The amount of $\mathrm{N}$ symbiotically fixed by the pigeonpea during the entire growth period was not significantly different between the two cropping systems in spite of the higher value in the intercrop (Table 5). This could be attributed to the considerable decrease in total dry matter yield when intercropped (Table 3 ). These observations are consistent with most studies on cereal/legume intercropping systems (Danso et al. 1987; Ofori et al. 1987; Papastylianou 1988; van Kessel and Roskoski 1988). The pigeonpea fixed $120-170 \mathrm{~kg} \mathrm{ha}^{-1}$ of atmospheric $\mathrm{N}_{2}$ during the 200 days of cultivation. Little information is available on the field evaluation of $\mathrm{N}_{2}$ fixation by pigeonpeas. Jena and Misra (1990) reported that a short-duration genotype of pigeonpea fixed around $15 \mathrm{~kg} \mathrm{~N}$ ha' in 30 days on soils fertilized with 10 or $20 \mathrm{~kg} \mathrm{~N}$ ha ', from 30 to 60 days after sowing. Using a medium-duration genotype of pigeonpea, Kumar Rao et al. (1987) estimated that $80-90 \mathrm{~kg} \mathrm{~N} \mathrm{ha}^{-1}$ was derived from air after 160 days. Some studies have reported a relatively high dependency of pigeonpea plants on $\mathrm{N}_{2}$ fixation, in the region of $90 \%$ (La Favre and Focht 1983; Kuman Rao et al. 1987).

\section{$\mathrm{N}$ transfer}

Although there is evidence of $\mathrm{N}$ transfer from legumes to associated cereals (Bandyopadhyay and De 1986; Patra et 